\title{
Submerged aquatic plant (Vallisneria spiralis and Egeria densa) utilisation as a biogas cleaner and feedstock of co-digestion
}

\author{
G. NAGY \\ University of Miskolc, Faculty of Materials Science and Engineering, Institute of Energy and Quality, \\ nagy.gabi@uni-miskolc.hu
}

\begin{abstract}
Biogas was produced from sheep manure and two types of submerged aquatic plant (Vallisneria spiralis and Egeria densa). The gas cleaning was carried out by a water scrubber, where a significant part of $\mathrm{CO}_{2}$ and $\mathrm{H}_{2} \mathrm{~S}$ can be separated from the gas. A part of water from the scrubber was circulated through an aquatic plant growth tank and the growth of used plants was examined.

Addition of E. densa to sheep manure increased gas yield by 8\% and the mixing of sheep manure and V. spiralis resulted in 21\% increase in gas yield. With the used scrubber, 70-80 vol\% methane content can be reached in the cleaned biogas, and the water from the scrubber (which contained dissolved $\mathrm{CO}_{2}$ and $\mathrm{H}_{2} \mathrm{~S}$ ) resulted in 56-87\% increase in size as opposed to $12-44 \%$ increase in the control group.
\end{abstract}

Keywords: biogas, biogas cleaning, Egeria densa, manure, sheep manure, Vallisneria spiralis

\section{Introduction}

Anaerobic digestion is a widely used treatment method for methane production from organic materials e.g. wastewater[1], manure [2], food waste [3], etc. During anaerobic digestion, the microorganisms decompose the organic matter in the absence of oxygen, and its main product will be biogas. As the biogas has high methane content, its primary application is heat and power generation via combustion. Beside biogas, the digestate is a useful material too, it is typically used as a soil improvement agent.

Most of biomass (including aquatic plants) are suitable for biogas production. Many publications deal with the potential of anaerobic digestion of marine and freshwater plants. Algae may serve as potential sources of biogas, but these technologies have considerable difficulties [4]. In a review of Marquez et al. [5], the opportunities of anaerobic fermentation of different seaweeds are presented. According to them, high gas yield can be expected in case of most seaweed species, even with the use of bacteria for the degradation of terrestrial plants.

In addition to salt water plants, freshwater plants can also be used in anaerobic fermentation. In case of these plants, they are usually used or studied as raw material for biogas production. Most of these 
live above and on the surface of the water, such as water hyacinth [6], or the seven types of wetland aquatic plants which were used by Jiang et al. [7].

Aquatic plants can also be advantageously used for co-fermentation with other starting materials. According to the paper of Tubassum et al. [8], mixing natural and cultivated seaweeds with dairy slurry can increase biomethane efficiency during biogas production. Allen et al. [9] studied the codigestion of fresh and dried green algae (Ulva lactuca) with dairy slurry at different ratios. Based on their observations, the disadvantage of sea weed fermentation can be reduced by the common fermentation.

Based on the present data, the aquatic plants may be appropriate for the co-digestion with another, lower quality feedstock. For example, such low-quality base material is sheep manure, according to literature [10] and our previous results, too [11]. In 2015, over 85 million sheep were recorded to be the part of the livestock population of the EU-28 [12]. Thus, despite being a low-quality base material, the exploitation of the manure of these livestock has a potential if mixed with another material.

In order to increase the efficiency of biogas utilization and to carry out the process in a more environmentally friendly way, the gas needs to be upgraded. One of the simplest way is the use of water scrubbing, which decreases the $\mathrm{CO}_{2}$ and $\mathrm{H}_{2} \mathrm{~S}$ content of the biogas [13]. The reduction of $\mathrm{CO}_{2}$ and $\mathrm{H}_{2} \mathrm{~S}$ content will significantly improve the quality of biogas by increasing the calorific value. In addition to water washing, the cleaning can be enhanced by using algae. Ramaraj and Dussadee summarized the biological biogas purifying methods and its results [14]. According to this review, gas cleaning with algae is self-sustaining with the addition of minimal nutrients and light, furthermore, it has several advantages over the conventional chemical $\mathrm{CO}_{2}$ reducing methods [14]. Moreover, Salafudin et al. [15] combined the water scrubbing and the $\mathrm{CO}_{2}$ binding ability of the plants. Using catfish pond water (which was overgrown with wild algae) as gas purifier, and the measured $\mathrm{CO}_{2}$ capture efficiency of the cleaning system was $50 \%$.

The aquatic plants used (Valisneria spiralis and Egeria densa) have high tolerance and have been widely distributed around the world [16]. The main properties of the aquatic plants are summarised in Table 1.

\begin{tabular}{|c|c|c|}
\hline Properties & Vallisneria spiralis & Egeria densa \\
\hline Regular height, $\mathrm{cm}$ & $30-100$ & $40-100$ \\
\hline $\begin{array}{l}\text { Optimal temperature } \\
\text { for growing, }{ }^{\circ} \mathrm{C}\end{array}$ & $15-30$ & $10-26$ \\
\hline Water hardness & soft - very hard & soft - very hard \\
\hline pH tolerance & $6-9$ & $5-10$ \\
\hline Growth & Fast & Fast \\
\hline Habitat & $\begin{array}{c}\text { static or flowing freshwater habitats, } \\
\text { (lakes, ponds, water courses, and } \\
\text { wetlands) }\end{array}$ & $\begin{array}{l}\text { inland lakes and rivers, often shallow, mild } \\
\text { or warm, still or slow-moving waters }\end{array}$ \\
\hline
\end{tabular}

Table 1. Properties of V. spiralis and E. densa [16, 17].

Numerous studies have already been carried out on the selected plants. For example, $V$. spiralis has high phytoremediation ability in case of polycyclic aromatic hydrocarbon (PAH) contaminated sediments [18]. Furthermore, this plant can accumulate high amount of cadmium, copper [19] and 
lead [20] from sediments. E. densa can accumulate the arsenic, zinc, aluminium [21] and selenium [22], as well as dissolved $\mathrm{H}_{2} \mathrm{~S}$ which has a positive effect for growth [23].

The goal of the experiments was to realize a sustainable lab-scale system, where the gas purification can be accomplished by aquatic plants that can be added to the fermenter as auxiliary feedstock. For this, V. spiralis and E. densa were used and the biogas production and composition were measured as well as the plants' length.

\section{Materials and methods}

The sheep manure originated from a livestock farm in Szendrö, and the plants ( $V$. spriralis and $E$. densa) were obtained from local aquarium shop (Miskolc). The photographs of the used base materials and aquatic plants are shown in Figure 1., the results of ultimate and proximate analysis of the sheep manure, the two types of aquatic plants and the used mixtures can be seen in Table 2 .
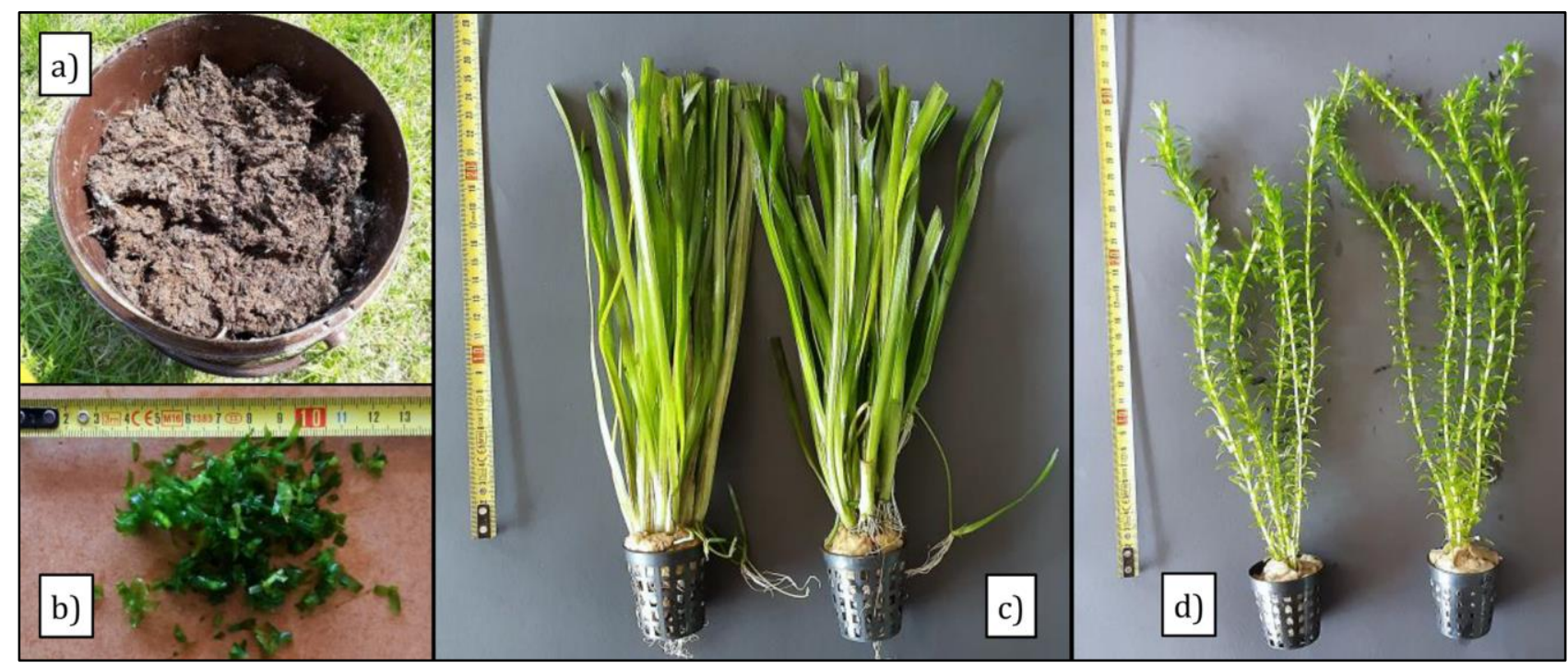

Figure 1. The used sheep manure (a), prepared E. densa (b) and the gas purifier V. spiralis (c) and Egeria densa (d).

\begin{tabular}{|c|c|c|c|c|c|c|c|}
\hline & \multicolumn{2}{|c|}{ Parameter } & $\begin{array}{l}\text { Sheep } \\
\text { manure }\end{array}$ & $\begin{array}{c}\text { Vallisneria } \\
\text { spiralis }\end{array}$ & $\begin{array}{c}\text { Egeria } \\
\text { densa }\end{array}$ & $\begin{array}{c}\text { Sheep manure + } \\
6 \text { wt.\% Vallisneria } \\
\text { spiralis (wet basis) }\end{array}$ & $\begin{array}{c}\text { Sheep manure + } \\
6 \text { wt.\% Egeria densa } \\
\text { (wet basis) }\end{array}$ \\
\hline \multirow{7}{*}{ 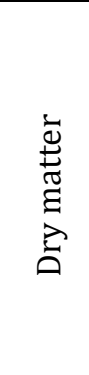 } & Nitrogen & \multirow{6}{*}{$\begin{array}{l}\stackrel{\circ}{3} \\
\stackrel{3}{3}\end{array}$} & 2.59 & 2.86 & 3.94 & 2.61 & 2.67 \\
\hline & Carbon & & 29.28 & 33.32 & 36.04 & 29.52 & 29.69 \\
\hline & Hydrogen & & 3.85 & 4.69 & 5.51 & 3.90 & 3.95 \\
\hline & Sulphur & & 0.70 & 0.65 & 0.44 & 0.70 & 0.68 \\
\hline & Oxygen & & 17.17 & 42.82 & 41.23 & 18.70 & 18.62 \\
\hline & Ash & & 46.42 & 15.66 & 12.48 & 44.57 & 44.38 \\
\hline & HHV & $\sum_{\sum}^{\infty}$ & 9.87 & 10.38 & 12.75 & - & - \\
\hline \multirow{2}{*}{ 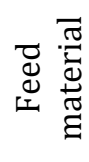 } & Moisture & $\frac{\partial}{3}$ & 51.98 & 93.41 & 92.05 & 10 & 10 \\
\hline & $\mathrm{pH}$ & ' & 7.68 & - & - & - & - \\
\hline
\end{tabular}

Table 2. Ultimate and proximate analysis of base materials. 
The schematic illustration of the lab-scale anaerobic digester system can be seen in Figure 2. The reactors were located in a $34{ }^{\circ} \mathrm{C}$ (mesophilic) water bath. The water scrubber operated without stopping during the experiment, but the water exchange between the water scrubber and the aquatic plant growing tank was batch. The water exchange worked 3 times a day for 60 minutes in total. This is 1 litre water change per day.

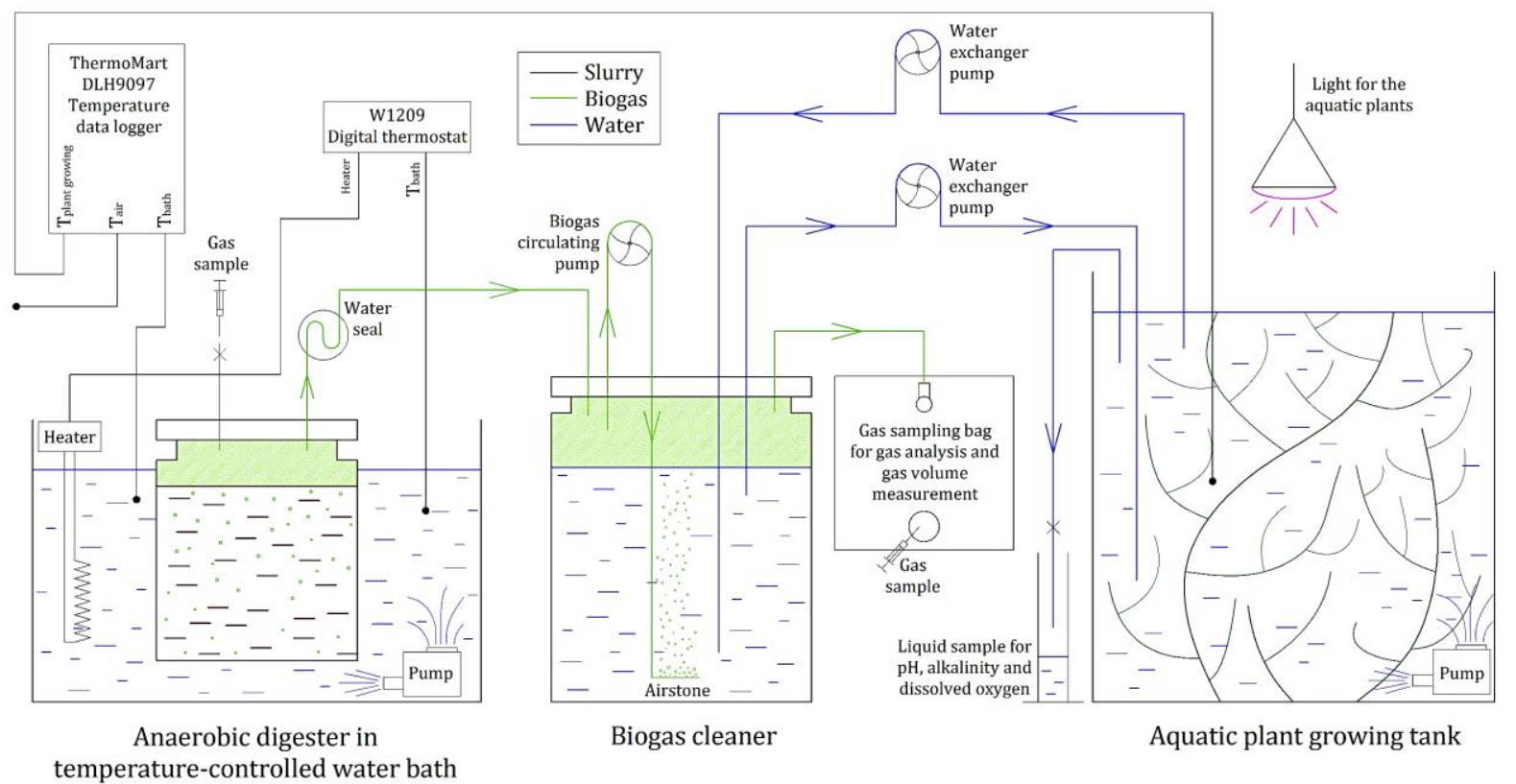

Figure 2. The lab-scale anaerobic digester system.

The produced gas was collected into a gas sampling bag and the amount of collected gas was measured every day. Gas samples were taken from both the sampling bags and reactors every 2-3 days and an Agilent 490 Micro-GC with a COX and a PPU modules were used for the analysis of $\mathrm{CO}_{2}, \mathrm{C}_{1}-\mathrm{C}_{4}, \mathrm{H}_{2}, \mathrm{H}_{2} \mathrm{~S}$, $\mathrm{CO}$, and $\mathrm{O}_{2}$ content of the raw and cleaned biogas. The calculations of the Higher Heating Value (HHV) were based on the gas composition and the HHV of components. The plants were taken out of the water weekly and the total length of the plants, excluding sprouts, was measured. The measured parameters of the used plants at the beginning of the experiment can be seen in Table 3.

\begin{tabular}{|c|c|c|c|c|}
\hline \multirow{2}{*}{ Properties } & \multicolumn{2}{|c|}{ Cleaner } & \multicolumn{2}{c|}{ Control group } \\
\cline { 2 - 5 } & V. spiralis & E. densa & V. spiralis & E. densa \\
\hline Number of sprouts, pcs & 1 & 0 & 1 & 0 \\
\hline Length of all plants, cm & 1105 & 155 & 1340 & 133 \\
\hline Number of leaves, pcs & 47 & - & 58 & - \\
\hline Number of stems, pcs & 3 & 5 & 3 & 5 \\
\hline
\end{tabular}

Table 3. The initial sizes of used aquatic plants.

\section{Results}

Based on daily gas production, the cumulative gas production can be seen in Figure 3.

The gas formation started on the first day, due to the fact that the manure came from a part of dung storage that has been operating for a long time period and certain decomposition processes have already begun. The aerobic gas production due to these processes finished in a week and the anaerobic 
bacterium cultures growing in the next 10-15 days resulted in more intense gas production. The degradation of sheep manure started first, at 12-13 days, and with additive materials, the gas production was more significant after 15-16 days. The intensity of gas production started decreasing at day 34 in case of sheep manure and around day 36-38 for the mixtures. The lowest gas production was observed in case of the sheep manure, which was below $88 \mathrm{~L}$ gas/ kg dry matter. The addition of 6 wt.\% E. densa resulted in 8\% higher gas yield, while the addition of 6 wt.\% V. spiralis induced 21\% increase in the gas yield.

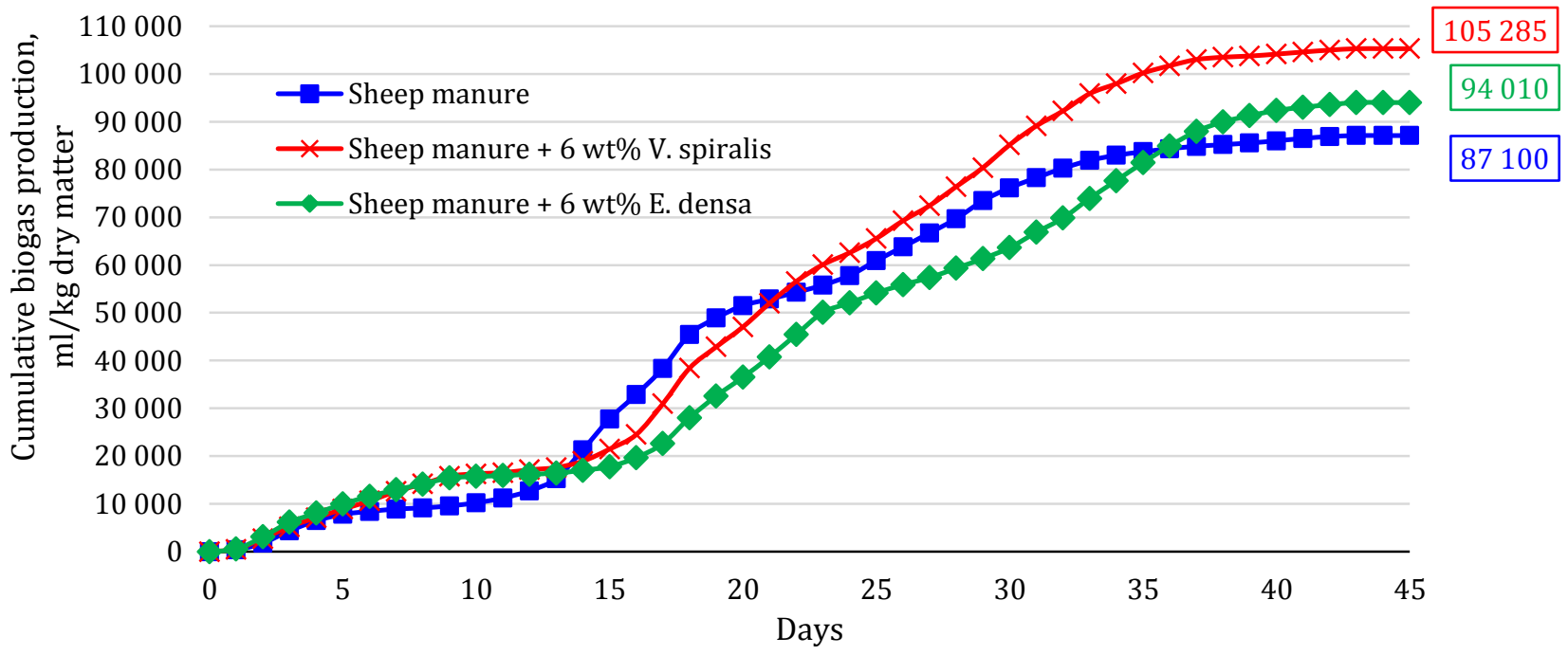

Figure 3. Cumulative biogas production.

The comparison of the composition of the formed biogas with the purified biogas composition is illustrated in Figure 4.
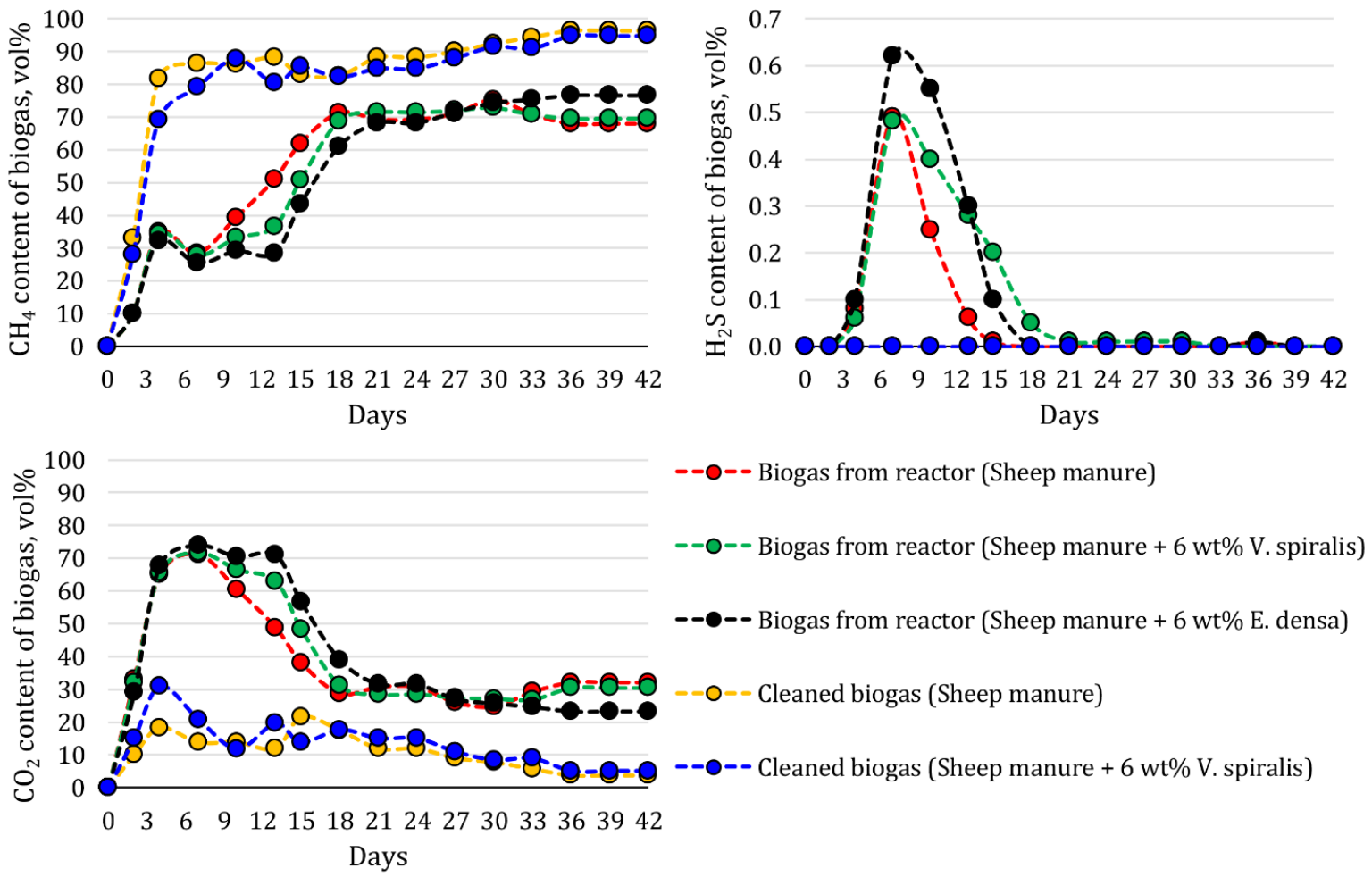

Figure 4. The changes of gas composition during the experiment. 
Based on Figure 4., the produced gas mainly contained $\mathrm{CH}_{4}$ and $\mathrm{CO}_{2}$, in 99 vol\%. The $\mathrm{CH}_{4}$ content in every reactor reached its maximum after 18-20 days, after it was around 70 vol\%. Due to the slower degradability of fresh additives, the increase in methane content was the fastest in case of sheep manure, however, the highest final $\mathrm{CH}_{4}$ content arose from the sheep manure-E. densa mixture. Figure 4 clearly shows the effect of scrubbing, as a stable $80-90 \mathrm{vol} \% \mathrm{CH}_{4}$ content can be reached with its use. In the last days of the experiment, with a small amount of gas formation, the methane content of the purified gas reached $95 \mathrm{vol} \%$.

$\mathrm{H}_{2} \mathrm{~S}$ formation was significant in the first 20 days of the experiment, during this period the maximum content of $\mathrm{H}_{2} \mathrm{~S}$ was 0.5-0.6. vol\%. Despite the two plants had a lower sulphur content than the manure (Table 2.), in case of the manure the $\mathrm{H}_{2} \mathrm{~S}$ content of the biogas was the lowest, which increased with the additives. After 20 days, the amount of $\mathrm{H}_{2} \mathrm{~S}$ was below the limit of detection ( $\left.0.01 \mathrm{vol} \%\right)$, however, the $\mathrm{H}_{2} \mathrm{~S}$ content of purified biogas was under $0.01 \mathrm{vol} \%$ during the whole duration of the experiment.

In addition to the components shown, some gas samples also contained hydrogen (max. 0.06 vol\%), carbon monoxide (0.07 vol\%) and other hydrocarbons (max. 0.03 vol\%).

Based on the gas composition, the HHVs were calculated and Figure 5. shows the changes of HHV in relation to the duration of the experiment. During the first 20 days, the HHV increased and then its value was $28 \pm 2 \mathrm{MJ} / \mathrm{m}^{3}$ as long as the experiment lasted. After the gas cleaning, the HHV increase was significant. By day 7, the HHV was over $30 \mathrm{MJ} / \mathrm{m}^{3}$ and it rose to $35-40 \mathrm{MJ} / \mathrm{m}^{3}$ in the last 12 days.

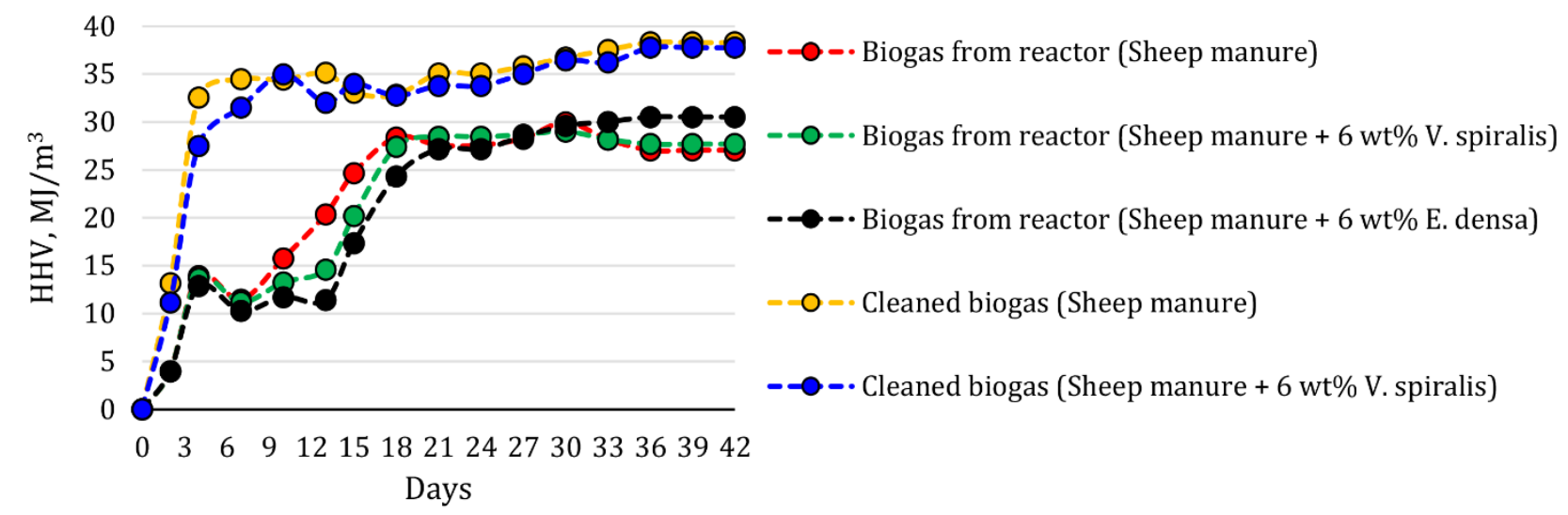

Figure 5. The changes of HHV of biogas during the experiment.

The water of the scrubber and of the plant growing tank was partially exchanged. The sizes of the plants growing in the exchanged water and the control group plants are illustrated in Figure 6. 100\% refers to the total length of leaves (for V. spiralis) and stems (for E. densa). Plants that also received water from scrubber grew significantly faster than the plants of the control group. In case of $V$. spiralis, for 6 weeks, the growing was 75\% faster but the number of sprouts was less (with 3) in case of cleaner plants than in the control group. In case of $E$. densa, the difference was $12 \%$ and the number of sprouts was higher (with 5 ) as a result of the scrubber water.

In case of $V$. spiralis, at the beginning of the experiment, cut leaves of uniform size did not grow any further, and some of them started to die slowly. In addition, the plants produced more sprouts in both 
tanks, but the size of the new ones had not been added to the size of the original plant. This caused the reduction in plant size towards the end of the experiment.
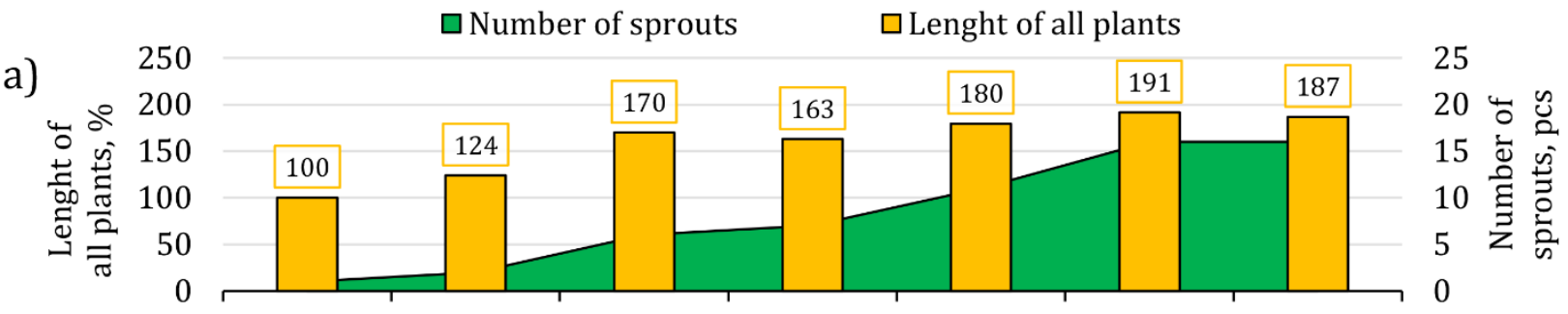

b) $\quad 250$
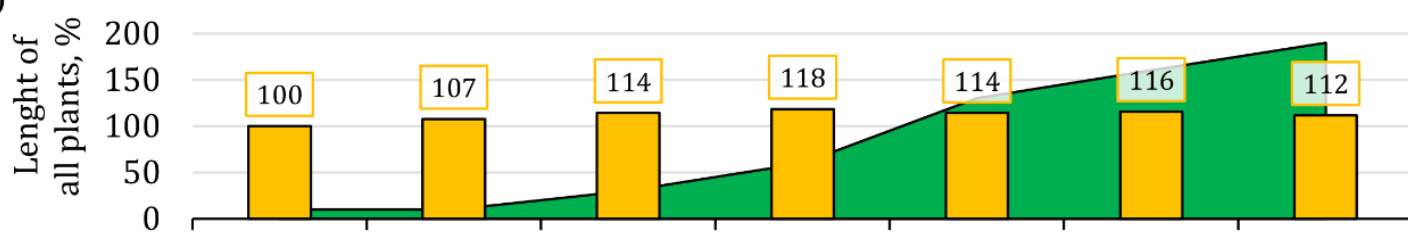

25

20 ㄴํㅇ

15 बे

10

5 之

c) 250

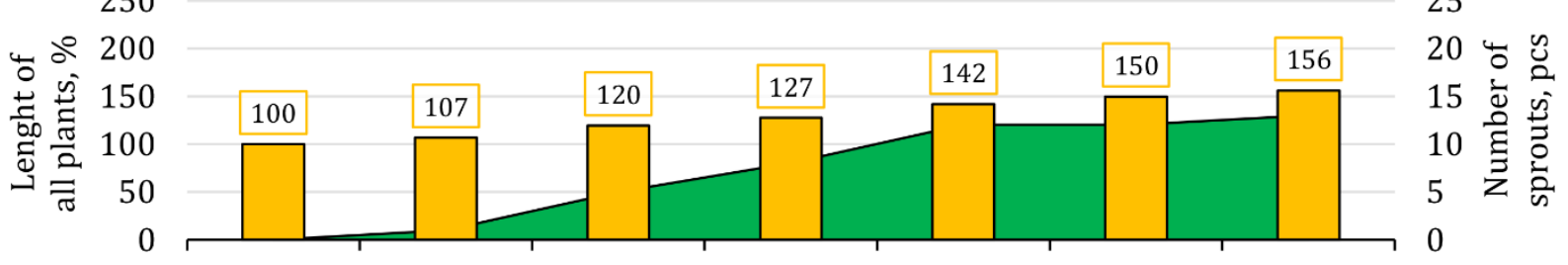

d)

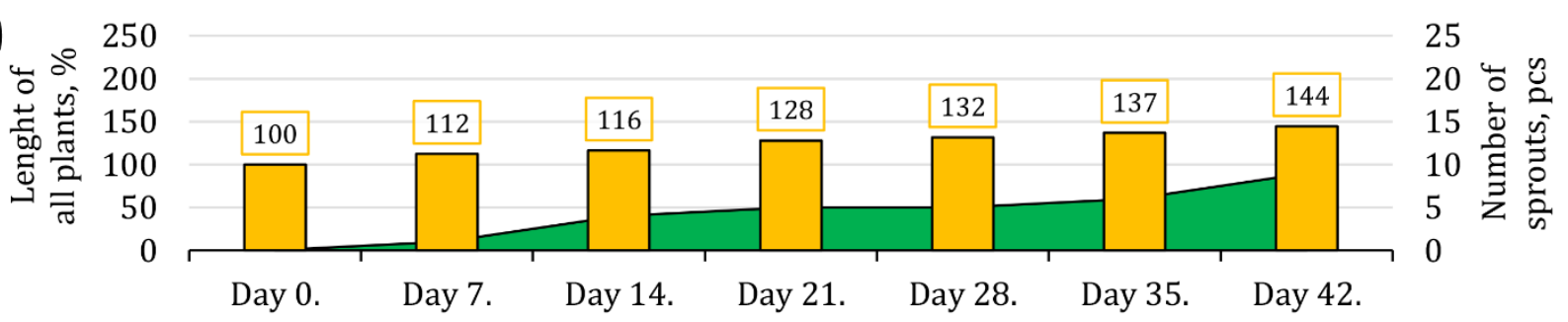

Figure 6. Plant growth and number of new sprouts during the experiment ( $a-V$. spiralis, cleaner; $b-V$. spiralis, control group; c - E. densa, cleaner; $d-E$. densa, control group).

\section{Conclusion}

Sheep manure was fermented at $34{ }^{\circ} \mathrm{C}$ with and without aquatic plants (Vallisneria spiralis and Egeria densa) and these plants were used as gas cleaner too. In the case of mixtures, the gas formation was more difficult to start, but in the case of both additives a larger amount of gas was formed. $6 \mathrm{wt} . \% \mathrm{~V}$. spiralis increased the gas quantity with $21 \%$, and $6 \mathrm{wt} . \%$ E. densa with $8 \%$. During all experiments, the methane content reached a maximum of $67-73$ vol\% and this period lasted 12 days. In contrast, the additives increased the $\mathrm{H}_{2} \mathrm{~S}$ content of the gas.

The water of scrubber absorbed significant amount of $\mathrm{CO}_{2}$, thereby, the $\mathrm{CO}_{2}$ content of gas decreased to $5-10 \mathrm{vol} \%$ by the end of the experiment. In addition, the $\mathrm{H}_{2} \mathrm{~S}$ content of the gas dropped below 0.01 vol\%.

From the water of the scrubber, the size of $V$. spiralis increased by $87 \%$ in 6 weeks, while plants in the control group grew by only $12 \%$. In case of E. densa the water of the scrubber caused $56 \%$ plant 
growth and significantly more sprouts were produced by the cleaning plants than the plants of control group.

\section{Acknowledgement}

The described article was carried out as part of the EFOP-3.6.1-16-2016-00011 "Younger and Renewing University - Innovative Knowledge City - institutional development of the University of Miskolc aiming at intelligent specialisation" project implemented in the framework of the Szechenyi 2020 program. The realization of this project is supported by the European Union, co-financed by the European Social Fund.

The author is grateful to Mária Ambrus for her linguistic advice.

\section{References}

[1] K. Barbusinski - K. Kalemba (2016) Use of Biological Methods for Removal of H2S from Biogas in Wastewater Treatment Plants - A Review. Architecture, Civil Engineering, Environment 9 (1) pp. 103-111.

[2] I. M. Nasir - T. I. M. Ghazi - R. Omar (2012) Anaerobic digestion technology in livestock manure treatment for biogas production: A review. Engineering in Life Sciences 12 (3) pp. 258-269.

[3] S. A. Elshimi - M. Elhousseini - B. E. Ali - M. M. Elshinnawi (1992) Biogas Generation from FoodProcessing Wastes. Resources Conservation and Recycling 6 (4) pp. 315-327.

[4] M. Debowski - M. Zielinski - A. Grala - M. Dudek (2013) Algae biomass as an alternative substrate in biogas production technologies-Review. Renewable \& Sustainable Energy Reviews 27 pp. 596-604.

[5] G. P. B. Marquez - W. J. E. Santianez - G. C. Trono - M. N. E. Montano - H. Araki - H. Takeuchi - T. Hasegawa (2014) Seaweed biomass of the Philippines: Sustainable feedstock for biogas production. Renewable \& Sustainable Energy Reviews 38 pp. 1056-1068.

[6] A. K. Mathew - I. Bhui - S. N. Banerjee - R. Goswami - A. K. Chakraborty - A. Shome - S. Balachandran - S. Chaudhury (2015) Biogas production from locally available aquatic weeds of Santiniketan through anaerobic digestion. Clean Technologies and Environmental Policy 17 (6) pp. 1681-1688.

[7] X. Y. Jiang - X. H. Song - Y. H. Chen - W. N. Zhang (2014) Research on biogas production potential of aquatic plants. Renewable Energy 69 pp. 97-102.

[8] M. R. Tabassum - D. M. Wall - J. D. Murphy (2016) Biogas production generated through continuous digestion of natural and cultivated seaweeds with dairy slurry. Bioresource Technology 219 pp. 228-238.

[9] E. Allen - D. M. Wall - C. Herrmann - J. D. Murphy (2014) Investigation of the optimal percentage of green seaweed that may be co-digested with dairy slurry to produce gaseous biofuel. Bioresource Technology 170 pp. 436-444.

[10] T. János - L. Blaskó (2008) Environmental management, Debreceni Egyetem, Debrecen.

[11] G. Nagy - A. Takács - A. A. Kállay - D. Mentes (2018) The anaerobic digestion of sheep manure in self-designed low-cost biogas reactor. Analecta Technica Szegedinensia 12 (2) pp. 13-23. 
[12] Eurostat, Sheep population - annual data. https://ec.europa.eu/eurostat/web/productsdatasets/-/apro_mt_lssheep (accessed 02. 02. 2019.)

[13] S. S. Kapdi - V. K. Vijay - S. K. Rajesh - R. Prasad (2005) Biogas scrubbing, compression and storage: perspective and prospectus in Indian context. Renewable Energy 30 (8) pp. 1195-1202.

[14] R. Ramaraj - N. Dussadee (2015) Biological purification processes for biogas using algae cultures: A review. International Journal of Sustainable and Green Energy 4 (1) pp. 20-32.

[15] Salafudin - R. H. Setyobudib - S. K. Wahono - A. Nindita - P. G. Adinurani - Y. A. Nugroho - A. Sasmito - T. Liwang (2015) Biological Purification System: Integrated Biogas from Small Anaerobic Digestion and Natural Microalgae. Procedia Chemistry 14 pp. 387-393.

[16] Invasive Species Compendium - Detailed coverage of invasive species threatening livelihoods and the environment worldwide. https://www.cabi.org/isc/ (accessed 12.08. 2019.)

[17] GREEN AQUA. https://www.greenaqua.hu/en/ (accessed 12. 08. 2019.)

[18] Y. He - J. Chi (2019) Pilot-scale demonstration of phytoremediation of PAH-contaminated sediments by Hydrilla verticillata and Vallisneria spiralis. Environmental Technology 40 (5) pp. 605-613.

[19] Q. A. Wang - Z. Li - S. P. Cheng - Z. B. Wu (2010) Influence of humic acids on the accumulation of copper and cadmium in Vallisneria spiralis L. from sediment. Environmental Earth Science 61 (6) pp. 1207-1213.

[20] M. Gupta - P. Chandra (1994) Lead Accumulation and Toxicity in Vallisneria-Spiralis (L) and Hydrilla-Verticillata (LF) Royale. Journal of Environmental Science and Health Part A: Environmental Science and Engineering and Toxicology 29 (3) pp. 503-516.

[21] A. F. Abu Bakar - I. Yusoff - N. T. Fatt - F. Othman - M. A. Ashraf (2013) Arsenic, Zinc, and Aluminium Removal from Gold Mine Wastewater Effluents and Accumulation by Submerged Aquatic Plants (Cabomba piauhyensis, Egeria densa, and Hydrilla verticillata). BioMed Research International, 2013 Article ID 890803.

[22] M. Ohlbaum - S. L. Wadgaonkar - J. J. A. van Bruggen - Y. V. Nancharaiah - P. N. L. Lens (2018) Phytoremediation of seleniferous soil leachate using the aquatic plants Lemna minor and Egeria densa. Ecological Engineering 120 pp. 321-328.

[23] M. Parveen - T. Asaeda - M. H. Rashid (2017) Effect of hydrogen sulfide exposure on the growth, oxidative stress and carbohydrate metabolism of Elodea nuttallii and Egeria densa. Fundamental and Applied Limnology 191 (1) pp. 53-62. 